\title{
PERCEPTIONS OF STAKEHOLDERS ON QUALITY OF HIGHER EDUCATION IN MIZORAM
}

\author{
Laltlanzauvi Kawlni \\ Research Scholar, Mizoram University \\ Lokanath Mishra \\ Professor, Department of Education Mizoram University
}

Article DOI: https://doi.org/10.36713/epra5891

\begin{abstract}
The topic of "quality" has received much concern in the context of higher education all over the world. Developing countries like India are also striving forward to improve their higher education system by taking various initiatives. Experts in the respected field have been envisaged that assessment of quality must incorporated the perceptions of its stakeholders. However, with reference to India, the quality of higher education has been assessed through external bodies and the quality of higher education has been hardly studied through its internal bodies particularly the primary stakeholders views were not actually taken into account. The present study is about studying the perceptions of the primary stakeholders on the key components of the higher education. The study will aid the authorities in reflecting and planning the higher education system in order to improve and maintain the quality.
\end{abstract}

KEYWORDS: Higher education, Quality, Perceptions of stakeholders, Mizoram.

\section{THEORETICAL BACKGROUND}

Quality Higher Education has proved to be the major tool for socio-economic development particularly for developing nations. Quality higher education enables empowerment by overcoming the limitations of physical resources. Thus, quality has been a major concern in higher education all over the world. India has been taking several steps and initiatives to improve its higher education. There has been improvement and development in terms of enrollment, establishment of institutions and gross enrollment ratio. For the maintenance and promotion of quality in the Indian higher education, the National Accreditation and Assessment Council (NAAC) as an autonomous body was established in 1994. The main objectives of NAAC are to grade institutions of higher education and their programmes; stimulate the academic environment and quality of teaching and research in these institutions; help institutions realize their academic objectives; promote necessary changes, innovations and reforms in all aspects of the institutions working for the above purpose; and encourage innovations, self-evaluation and accountability in higher education. (NAAC, 2006). It is envisaged by experts that every institution should have assessment and accreditation by NAAC, for better quality and is also evident from many studies that Assessment and Accreditation would enable institutions to upgrade and achieve higher standard.

Mizoram is one of the mountainous states of India with Aizawl as its capital. It has a total area of approximately $21,081 \mathrm{sq}$. $\mathrm{km}$. It shares international boundary with Myanmar in the south and east, and Bangladesh in the west, it is also bounded in the west by Tripura and in the north by the states of Assam and Manipur. Thus, Mizoram occupies an area of great strategic importance in the north eastern corner of India. According to the Census 2011, the total population of Mizoram is 10,91,014 and is the second highest among the states in terms of literacy rate with $91.3 \%$ only after Kerela. 


\section{EPRA International Journal of Research and Development (IJRD)}

Mizoram had its first college in 1958 at its capital, Aizawl and the first and the only Central University called Mizoram University was opened in 2001. At present, the total number of all higher education institutions in the state is 50 out of which there are 3 Universities, 32 colleges and 15 stand alone institutions. There is only 1 constituent college of Mizoram University, i.e., Pachhunga University College. There are 27 Colleges under Section 2(f) and $12 \mathrm{~B}$ of the UGC Act 1956 and 2 Colleges under Section 2(f). There are 24 colleges and 1 University which were accredited so far by NAAC as on March, 2020. Out of 21 government colleges offering general education, only 19 of them have been so far assessed and accredited. Out of the 19 colleges, 2nd Cycle assessment of 11 colleges and $3^{\text {rd }}$ cycle assessment of 1 college has also been completed and accredited. In assessment of both the cycles, the overall grades of the colleges fell within the ranges of $\mathrm{C}, \mathrm{C}+, \mathrm{C}++$ to $\mathrm{B}, \mathrm{B}++$. As of today, there are only 17 colleges whose accreditation period is valid. Gross Enrolment Ratio in Mizoram is 25.7 of which 26.5 male and 24.8 female in 2018-2019. Number of student enrolment in general degree colleges of undergraduate level is 19863 during the period 201819. The pupil teacher ratio in higher education in Mizoram is 18 and the Gender Parity Index (GPI) is 0.94 .

\section{SIGNIFICANCE OF THE STUDY}

The term quality has received increasing attention in the last twenty years in higher education. Quality assessment as a mechanism of quality improvement in higher education has spread all over the world over a period of time. The quality is an industrial term commonly used to refer the degree of excellence and standard of products or goods and commodities set by the producers and manufacturers to satisfy the customer needs and thus, to stay in business. The traditional concept of quality is associated with the idea of providing a product or service that is distinctive and special, and which confers status on the owner or user. (Pfeiffer and Coote, 1991). The meaning of quality has been explained in relation to its dictionary meaning by various renowned authors, who are pioneers in establishing quality systems. According to Oxford Dictionary, Quality is degree, especially high degree of goodness or worth, while Webster's Dictionary defines it as Grade of Excellence. Bureau of Indian Standards, 1988 defines quality as "the totality of features and characteristics of a product or service that bear on its ability to satisfy stated or implied needs."

The quality of higher education is a result of collective effort of all stakeholders in higher education, which includes the state, the society, the employer, parents, the management, teachers and students. Enhancing quality is a holistic process.
Isolated efforts in improving the quality of a few selected components of the education system such as the infrastructure, teacher training, research funding or industry participation would be of limited value (Anandakrishnan, 2007). Therefore, all the stakeholders in higher education need to pay attention in strengthening the academic and the nonacademic tools, and use them in holistic manner to enhance the quality of higher education. Tang and Hussin (2011) opined that in higher education, stakeholders' views are crucial and should be taken into consideration by the education providers in transcending cognitive skills as well as improving quality processes. Rajasingh (2009) also suggested that quality of higher education cannot be achieved without knowing the perceptions of stakeholders and their perceptual divide. Students and teachers are the largest group within any HEI, and therefore are the main stakeholders who have a much stronger voice than any other stakeholders. As such, the perceptions of students and teachers are one of the most important to know the conditions and standard of Higher Education systems. The interest and participation of students and teachers at all levels in both internal quality assurance and external quality assurance have to play a central role. It makes the process of quality assurance and quality enhancement for the institution more reliable and credible. To date in Mizoram, quality of higher education has been assessed through NAAC only and the perceptions of its stakeholders have never been reflected incorporated into the assessment process. Therefore, students' and teachers' perceptions on quality in higher education can help in effective monitoring of quality in higher education in the state and it is hoped that this study will aid the development of the system by bringing in suggestions to the policy makers which will enhance the quality of higher education institutions in Mizoram.

Hence, the study of perceptions of all stakeholders on quality of higher education is the need of the hour for effective quality assessment of higher education in the state as it is often said that quality of higher education cannot be achieved practically without knowing the perceptions of stakeholders.

\section{OBJECTIVES OF THE STUDY}

The overall aim of the present study is to examine the perceptions of stakeholders (students, teachers) in general degree colleges of Mizoram. The specific objectives of the study is to examine the perception of stakeholders on the quality of infrastructure and instructional facilities available in the general degree colleges of Mizoram. 


\section{EPRA International Journal of Research and Development (IJRD) \\ Volume: 5 | Issue: 12 | December 2020 \\ - Peer Reviewed Journal}

\section{METHODOLOGY OF THE STUDY}

A descriptive survey method was used for the present study. The study is also quantitative in nature as structured questions along with fixed responses were used in questionnaire to elicit the perceptions of stakeholders on quality of higher education. The study covers all the general degree colleges of Mizoram affiliating to Mizoram University. In Mizoram, there are 21 affiliated government general degree colleges. So the population for the study includes all the students and teachers in these 21 colleges. Selection of sample for the present study was simple random sampling in nature. 10 teachers and 20 students from each degree college of Mizoram i.e. 210 teachers and 420 students were selected randomly. The investigator developed questionnaire for the present study as there was no readymade questionnaire which was relevant for the present study. The questionnaire was developed for the students and teachers of government general degree colleges in Mizoram to examine the perceptions on quality of higher education in Mizoram. The developed questionnaire was validated using content validity and the reliability of the tool developed was found using test retest method .Keeping in view the objectives of the study and nature of data, descriptive techniques such as percentages was employed for the analysis and interpretation of data. Tabulation of data for percentages was done manually.

\section{FINDINGS OF THE STUDY}

Findings on perceptions of stakeholders on the overall Quality of infrastructure and instructional facilities in the general degree colleges of Mizoram.

\begin{tabular}{|l|c|c|c|c|}
\hline \multicolumn{1}{|c|}{$\begin{array}{c}\text { Quality of infrastructure and } \\
\text { instructional facilities in the colleges. }\end{array}$} & Very Good & Good & Poor & Very Poor \\
\hline Perceptions of students & 20.98 & 47.88 & 14.44 & 16.7 \\
\hline Perceptions of Teachers & 10 & 52.75 & 28.43 & 8.82 \\
\hline Perceptions of Students and Teachers & $\mathbf{1 5 . 5}$ & $\mathbf{5 0 . 3 1}$ & $\mathbf{2 1 . 4 3}$ & $\mathbf{1 2 . 7 6}$ \\
\hline
\end{tabular}

The findings reveal that majority of the students were satisfied with the quality of the infrastructure and instructional facilities. However, more number of students perceived that computer facilities and internet connections in the college were very poor. The findings also reveal that more students perceived that the transport facilities in the general degree college of Mizoram were very poor and more number of the teachers perceived that recreational centres available in the degree general college of Mizoram were poor.
From the above table, it was shown that out of 630 respondents, majority i.e. $50.31 \%$ of the respondents perceived that the quality of infrastructure and infrastructural facilities were good, $15.5 \%$ of the respondents perceived that the quality of infrastructure and infrastructural facilities were very good, $21.43 \%$ of the respondents perceived as poor and $12.76 \%$ perceived as very poor. Thus, majority of the respondents perceived that the overall quality of infrastructure and instructional facilities available in the government general colleges of Mizoram were good.

Findings on perceptions of stakeholders on the overall quality of curriculum transacted in the general degree colleges of Mizoram.

\begin{tabular}{|c|c|c|c|c|}
\hline $\begin{array}{c}\text { Quality of curriculum transacted in the } \\
\text { colleges. }\end{array}$ & Very Good & Good & Poor & Very Poor \\
\hline Perceptions of students & 33.02 & 43.18 & 17.03 & 6.77 \\
\hline Perceptions of Teachers & 29.12 & 50.27 & 19.05 & 1.56 \\
\hline Perceptions of Students and Teachers & $\mathbf{3 1 . 0 7}$ & $\mathbf{4 6 . 7 3}$ & $\mathbf{1 8 . 0 4}$ & $\mathbf{4 . 1 6}$ \\
\hline
\end{tabular}

From the above table, it is revealed that a large number of respondents, i.e., $46.73 \%$ opined that the quality of curriculum transacted in the college was good, $31.07 \%$ perceived that it was very good, $18.04 \%$ perceived that quality of curriculum transacted in the college was poor and only $4.16 \%$ of the respondents opined it as very poor. Thus, it can be said that more number of the respondents perceived that the quality of curriculum transacted in the government general degree college were good and only a very low percentage of the respondents perceived as very poor. 
Findings on perceptions of stakeholders on the overall quality of student support services in the degree colleges of Mizoram.

\begin{tabular}{|c|c|c|c|c|}
\hline $\begin{array}{c}\text { Quality regarding student support service in the } \\
\text { colleges. }\end{array}$ & Very Good & Good & Poor & Very Poor \\
\hline Perceptions of students & 30.1 & 54.12 & 10.64 & 5.14 \\
\hline Perceptions of Teachers & 18.89 & 71.91 & 8.10 & 1.10 \\
\hline Perceptions of Students and Teachers & $\mathbf{2 4 . 5}$ & $\mathbf{6 3 . 0 1}$ & $\mathbf{9 . 3 7}$ & $\mathbf{3 . 1 2}$ \\
\hline
\end{tabular}

The Perceptions of the total respondents on quality regarding student support service in the college is shown in the above table and it implies that majority of them, i.e., $63.01 \%$ perceived it as good, $24.5 \%$ of them perceived that it was very good, only $9.37 \%$ and $3.12 \%$ respondents perceived it as poor and very poor.

Findings on the perceptions of stakeholders on the overall quality regarding research and innovation in the degree colleges of Mizoram.

\begin{tabular}{|c|c|c|c|c|}
\hline $\begin{array}{c}\text { Quality regarding research and innovation } \\
\text { in the colleges. }\end{array}$ & Very Good & Good & Poor & Very Poor \\
\hline Perceptions of students & 18.09 & 64.52 & 8.09 & 9.3 \\
\hline Perceptions of Teachers & 17.8 & 47.5 & 30.4 & 4.3 \\
\hline Perceptions of Students and Teachers & $\mathbf{1 7 . 9 4}$ & $\mathbf{5 6 . 0 1}$ & $\mathbf{1 9 . 2 4}$ & $\mathbf{6 . 8}$ \\
\hline
\end{tabular}

The above table shows the Perceptions of the 630 respondents on quality regarding research and innovation in the college and it was observed that $17.94 \%$ of them opined that it was very good, $56.01 \%$ of them perceived it as good, $19.24 \%$ of the respondents perceived that the quality regarding research and innovation in the college was poor and $6.8 \%$ of them perceived it as very poor. Therefore, the table implies that majority of the respondents perceived that the overall quality regarding research and innovation in the government general degree colleges were good.

Findings on the perceptions of stakeholders on the overall quality regarding examination and evaluation practices of the degree colleges of Mizoram.

\begin{tabular}{|c|c|c|c|c|}
\hline $\begin{array}{c}\text { Quality regarding examination and evaluation } \\
\text { practices in the colleges. }\end{array}$ & Very Good & Good & Poor & Very Poor \\
\hline Perceptions of students & 52.22 & 33.73 & 10.16 & 3.89 \\
\hline Perceptions of Teachers & 41.6 & 49.04 & 7.62 & 1.74 \\
\hline Perceptions of Students and Teachers & $\mathbf{4 6 . 9 1}$ & $\mathbf{4 1 . 3 9}$ & $\mathbf{8 . 9}$ & $\mathbf{2 . 8 0}$ \\
\hline
\end{tabular}

The Perceptions of the total respondents on quality regarding examination and evaluation practices in the college is presented in the above table and it is observed that $46.91 \%$ of the respondents perceived that it was very good, $41.39 \%$ of them perceived that it was good, $8.9 \%$ respondents perceived it as poor and $2.80 \%$ of the respondents opined that it was very poor. Though the findings reveal that the total respondents' perceptions on the quality regarding examination and evaluation practices in the government general degree colleges were positive, yet the findings also reveal that there exist a difference in the perception of students and teachers on the same. While majority of the students perceived it as very good, majority of the teachers perceived as good. 
Findings on the perceptions of stakeholders on the overall quality regarding governance and leadership practices in the general degree colleges.

\begin{tabular}{|l|l|l|l|l|}
\hline $\begin{array}{l}\text { Quality regarding governance and leadership } \\
\text { practices in the colleges. }\end{array}$ & Very Good & Good & Poor & Very Poor \\
\hline Perceptions of students & 48.32 & 34.05 & 12.63 & 5 \\
\hline Perceptions of Teachers & 37.19 & 53.29 & 6 & 3.52 \\
\hline Perceptions of Students and Teachers & $\mathbf{4 2 . 7 6}$ & $\mathbf{4 3 . 6 7}$ & $\mathbf{9 . 3 1}$ & $\mathbf{4 . 2 6}$ \\
\hline
\end{tabular}

From the above table, it is observed that $42.76 \%$ of the respondents opined that the quality regarding governance and leadership practices in the college was very good, $43.67 \%$ of them perceived that it was good, while $9.31 \%$ of them opined it as poor and only $4.26 \%$ of the respondents perceived the quality regarding governance and leadership practices in the college as very poor. Therefore, a small majority of the respondents perceived that the overall quality regarding governance and leadership practices in the government general degree colleges was good though there is a slight difference in the perceptions between students and teachers while a small majority of the students perceived it as very good, majority of the teachers perceived it as good.

\section{CONCLUSIONS}

The quality of human resources in a country depends largely on the quality of higher education institutions and the quality of higher education largely depends on all the stake holders. Though there has been increase in enrolment, institutions, and human resources, the expansion and quality of higher education in Mizoram is still low in comparison to other states in the countries which clearly depicted that the higher education in Mizoram is very far from the international standard. The grade of the colleges in Mizoram accredited by NAAC reveals that the higher education in Mizoram has a long way to go to become a centre of excellence as well as to meet the international standard. On the contrary, the present study shows that the main stakeholders of higher education viz. students and teachers perceived that the quality of higher education is good. These contrasting results may be the very concept of good quality education is not widely understood by the stakeholders or may be the awareness level of stakeholders on quality education is low. Therefore, these contrasting results necessitated that awareness concerning quality of education must be organized frequently.

The state government should do an in-depth study of the performance of colleges on various criteria of assessment and accreditation of NAAC, and work its plan and strategies for the improvement of quality of its colleges. The present study reveals that the quality of higher education in Mizoram is not very deprived to become a centre of excellence. There are several strength areas as far as the quality of higher education in Mizoram is concerned which need to be maintained and promoted. However, many student support services such as career guidance cell, internet facilities, women's cell, human rights cell, grievance redressal cell, students counselling centre etc. must be established in every college for uplifting the standard of the higher education. The functioning of various committees constituted for academic and administrative purposes may be made more effective and efficient. Transparent, participative and accountable administrative practices need to be adopted. Internal Quality Assurance Cell (IQAC) must be made more practical to chalk out plan for quality initiatives and also monitor all the quality enhancement programmes conducted by the institution. Since government colleges are totally controlled by state government and Central University, many things may be delegated. So some kind of autonomy is required for these colleges like full or more autonomy to introduce new courses may be given to the colleges on criteria or norm based so that job-oriented courses like forestry, fisheries, farming, poultry, architecture, music, IT-oriented and Agro based courses which are relevant to the society for economic development of the state may be introduced. The state government may also introduce and monitor teacher's self-appraisal and student's feedback in all colleges more adequately. Therefore, it can be said that expansion of higher education particularly at collegiate level needs to be carried out in a planned manner, keeping in view the requirement of human resources and also to meet the needs of the society.

\section{REFERENCES}

1. All India Survey on Higher Education (AISHE) (2018-2019). Retrieved from http://aishe.nic.in/aishe/viewDocument.action?do cumentId $=263$

2. Anandkrishnan, M. (2006). Imperatives of Student Involvement in Quality Enhancement. Proceeding of International perspectives on student participation in Quality enhancement, 1 - 3.

3. Kalirajan, R. (2010). Demand for Quality Higher Education and Efficiency Inequality among Students in Salem District. Ph.D Thesis.Retrieved from http://hdl.handle.net/10603/27821

4. Kaur, Daljit (2013). Quality Assurance in Higher Education: An Evaluative Study. Ph.d Thesis. Retrieved from http://hdl.handle.net/10603/36767 


\section{EPRA International Journal of Research and Development (IJRD)}

Volume: 5 | Issue: 12 | December 2020

- Peer Reviewed Journal

5. NAAC (2006). Quality Assurance in Higher Education: An Introduction. Bangalore, India: National Assessment and Accreditation Council.

6. NAAC. Student Participation in Quality Enhancement. Retrieved from http://www.naac.gov.in/docs/Students\%20Partici pation\%20in\%20Quality\%20En hancement.pdf

7. Pfeffer, N. \& Coote, A. (1991). Is Quality Good for You? A Critical Review of Quality Assurance in the Welfare Services. London: Institute of Public Policy Research.

8. Pramod, Tandon and Gupta, P K (2008). Quality and Relevance in Higher Education. University News, 46(46):14-29.

9. Rajasingh,S. (2009) . Quality Assessment in Higher Education. Ph.d Thesis. Retrieved from http://shodhganga.inflibnet.ac.in/handle/10603/2 6765 